\title{
Daya Tarik Rasa Takut Pada Visualisasi Komunikasi Lingkungan
}

\author{
Lukki Lukitawati, Nur Indah Wuriani \\ Magister Ilmu Komunikasi, Universitas Diponegoro, Semarang, Indonesia \\ e-mail: lukkilukitawati@student.undip.ac.id, indahsalimin@students.undip.ac.id
}

\begin{abstract}
This study conduct discourse analysis on air pollution impact visualization of Aku dan Polusi campaign images. Visualisation is a vital strategies on shaping public perception of a complex and distant environmental issue. Aku dan Polusi deployed a series of emotive photo, headline and caption to visualize scientific research of air pollution impact. This study analyzed four chosen campaign images using children as actors with fearful headlines from multimodal discourse analysis perspective. Specifically, this study described two discursive strategies being employed on the campaign, 1) the use of fear appeals approach in visualizing the effects of air pollution and 2) the use of children as actors to evoke emotional reactions from the campaign target, namely parents, especially mothers. The findings of this study underlines potential exploitation of using vulnerable group in order to raise public awareness on an environmental issue. Represent the vulnerable group as the one who shouldered the burden of fixing environmental problem will exclude policy maker responsibility out of the text at the same time.
\end{abstract}

Keywords : multimodal discourse analysis, visualization, fear appeals, environmental communication.

\begin{abstract}
Abstrak
Penelitian ini melakukan analisis wacana pada visualisasi dampak polusi udara Kampanye Instagram Aku dan Polusi. Penggunaan visualisasi pada komunikasi lingkungan sebagai alat untuk membentuk persepsi publik sangat vital dalam menyampaikan permasalahan lingkungan yang kompleks dan cenderung berjarak dengan khalayak. Konten kampanye Instagram Aku dan Polusi menggunakan foto disertai headline dan caption sebagai visualisasi penelitian ilmiah mengenai dampak polusi udara. Pilihan visual dan leksikal empat unit analisis berupa foto yang menampilkan anak sebagai aktor, disertai headline yang emosional, diteliti dengan kerangka pemikiran multimodal discourse analysis. Penelitian ini mengidentifikasi strategi wacana yang digunakan dalam konten kampanye Aku dan Polusi yaitu penggunaan pendekatan daya tarik rasa takut (fear appeals) dalam visualisasi dampak polusi udara dan penggunaan anak dalam demand image yang memicu reaksi emosional target kampanye yaitu orang tua, terutama ibu. Hasil analisis menunjukkan adanya potensi eksploitasi kelompok rentan sebagai aktor sosial dalam upaya meningkatkan kesadaran terhadap suatu isu lingkungan dengan menempatkan kelompok rentan sebagai pihak yang harus ikut bertanggung jawab menyelesaikan permasalahan lingkungan dan mengeluarkan kelompok tertentu sebagai penyebab utama permasalahan lingkungan dari pembicaraan dalam hal ini adalah pembuat kebijakan.
\end{abstract}

Kata kunci: multimodal discourse analysis, visualisasi, fear appeals, komunikasi lingkungan. 


\section{Pendahuluan}

Visualisasi dapat secara signifikan memengaruhi persepsi risiko individu dengan mempercepat pemahaman mereka akan suatu isu dan membangkitkan respons emosional, terutama dalam komunikasi suatu isu yang kompleks seperti komunikasi lingkungan (Nicholson-Cole, 2005; Seo, Dillard, \& Shen, 2013). Oleh karenanya, dapat diterima bahwa visualisasi penelitian lingkungan dianggap sebagai ujung tombak komunikasi lingkungan. Visualisasi penelitian lingkungan, salah satunya dilakukan oleh gerakan advokasi Inisiatif Bersihkan Udara Koalisi Semesta (selanjutnya disebut Gerakan Ibukota) yang meluncurkan kampanye Aku dan Polusi melalui Instagram dengan sebagian besar konten berisi visualisasi penelitian ilmiah dampak polusi udara.

Gerakan Ibukota yang terdiri dari Greenpeace Indonesia, Walhi, Lembaga Bantuan Hukum Jakarta, dan Indonesian Center Environment Law serta beberapa individu atas nama Inayah Wahid, Melanie Subono dan 29 orang lainnya, mengajukan gugatan warga negara atau citizen law suit atas buruknya kualitas udara Jakarta. Gugatan tersebut didaftarkan di Pengadilan Negeri Jakarta Pusat (Mongabay, 2019) dengan nomor perkara 374/Pdt.G/LH/2019/PNJkt.Pst dengan tuntutan yang ditujukan kepada Presiden Republik Indonesia, Menteri Lingkungan
Hidup dan Kehutanan, Menteri Dalam Negeri, Gubernur Jakarta, Gubernur Jawa Barat dan Gubernur Banten sebagai tergugat (Indonesian Center For Environmental Law, 2019). Fokus utama gugatan warga negara ini adalah pada para pemangku kepentingan dan pembuat kebijakan yang abai mengumumkan kualitas udara yang sedang tidak sehat (Nathania \& Fadhillah, 2020).

Selain mengajukan tuntutan ke Pengadilan, Gerakan Ibukota juga meluncurkan kampanye daring Aku dan Polusi melalui Instagram. Sebanyak 121 material kampanye berbentuk unggahan Instagram diunggah sejak Oktober 2018 hingga Januari 2020. Rangkaian konten sebagian besar menggunakan foto dengan headline emosional disertai caption mengenai hasil penelitian dampak polusi udara untuk menarik perhatian masyarakat akan ancaman buruknya kualitas udara Jakarta agar masyarakat tergerak untuk terlibat dalam mitigasi polusi udara dan mendukung kampanye advokasi Aku dan Polusi.

Konten kampanye Aku dan Polusi menggunakan anak sebagai aktor visualisasi ancaman buruknya kualitas udara Jakarta. Beberapa unggahan yang digunakan dalam kampanye ini berupa foto anak yang memandang ke arah khalayak disertai headline yang memancing rasa takut dan caption mengenai penelitian - 
penelitian terkait ancaman kualitas udara yang buruk.

Fear appeals, pendekatan komunikasi yang membangkitkan rasa takut atau cemas, banyak digunakan untuk mengantarkan visualisasi mengenai isu lingkungan karena dianggap mampu menekankan risiko yang dihadapi dan tanggung jawab personal akan suatu isu serta menarik perhatian khalayak di antara arus informasi yang sangat masif (Reser \& Bradley, 2017). Fear appeals biasa digunakan penyusun strategi kampanye untuk memunculkan respons emosional terhadap sebuah ancaman yang dirasakan dan diterima melalui berbagai bentuk komunikasi. Fear appeals bekerja dengan asumsi bahwa ketika khalayak melihat fear inducing messages, maka akan muncul reaksi terhadap pesan tersebut sehingga menimbulkan kegelisahan, yang hanya bisa dihilangkan dengan cara berhenti melakukan perilaku yang diuraikan pada pesan tersebut (Ruiter \& Kok, 2012).

Visualisasi dampak suatu isu lingkungan yang dramatik dan berpotensi membangkitkan rasa takut adalah taktik yang efektif menarik perhatian khalayak. Visualisasi yang emosional mampu membuat suatu isu lingkungan terlihat penting dan powerful (Nicholson-Cole, 2005). Penelitian menunjukkan bahwa penggunaan visualisasi yang sensasional bisa memunculkan banyak problematika etis seperti kecenderungan menyasar kelompok rentan, fear mongering dan kontra produktif (Moser \& Dilling, 2004; O’Neill \& Nicholson-Cole, 2009).

Meskipun penelitian tentang komunikasi lingkungan baik verbal dan tertulis sangat berkembang, namun sedikit sekali yang fokus membahas mengenai komunikasi lingkungan dengan media visual. Kurangnya penelitian dengan fokus tersebut, membuat pemahaman terhadap penggunaan foto atau gambar dalam visualisasi suatu penelitian ilmiah terkait isu lingkungan dan bagaimana visualisasi ini membentuk persepsi publik tentang isu lingkungan tersebut menjadi kurang berkembang.

Dengan asumsi penelitian bahwa visualisasi dampak isu lingkungan yang dramatik dan emosional mempunyai kecenderungan untuk melebih - lebihkan dan sarat akan ideologi tertentu, penelitian ini berusaha memberikan gambaran kritis akan pilihan visual dan leksikal tertentu pada visualisasi dampak polusi udara. Penggunaan anak sebagai aktor visualisasi dampak polusi udara membangun makna tertentu yang patut dipertanyakan.

Wacana dari teks yang memiliki mode lebih dari satu seperti konten kampanye Aku dan Polusi disebut sebagai teks multimodal. Multimodal Discourse Analysis mampu memberikan gambaran bagaimana pilihan visual dan leksikal 
mampu menyusun konstruksi makna, dan membaginya menjadi representasional, interactive dan compositional meaning yang melihat teks multimodal bisa digunakan untuk merepresentasikan suatu nilai, berinteraksi antara produsen dan khalayak serta setiap modenya mampu melengkapi makna satu sama lain. Dengan latar belakang tersebut, rumusan masalah penelitian ini adalah 1) bagaimana anak ditampilkan dalam kampanye Instagram Aku Polusi? 2) apa strategi yang digunakan untuk menampilkan anak dalam kampanye Instagram Aku dan Polusi?

\section{Metode Penelitian}

Penelitian ini menggunakan multimodal discourse analysis (MDA) dengan langkah-langkah pengumpulan data sebagai berikut :

Langkah 1: Mengumpulkan dan membuat pencatatan data (logging). Pada tahap ini, material kampanye Instagram Aku dan Polusi dikumpulkan dan dicatat secara kronologis. Catatan berupa image/video dan caption log dengan catatan deskriptif untuk setiap gambar dan foto.

Langkah 2: Observasi data. MDA melibatkan langkah observasi data secara berulang dan terus menerus. Demikian pula dalam penelitian ini, observasi material kampanye Instagram Aku dan Polusi berupa unggahan Instagram juga akan dilakukan secara berulang dan terus menerus. Fokus akan berubah seiring perkembangan penelitian, seperti mode image/video lalu caption dan penggabungan keduanya dengan terus mengacu pada pertanyaan penelitian. Melihat data dengan $\log$ dan mengaturnya bertujuan untuk menyaring dan memunculkan pertanyaan dan mengembangkan ide-ide analitis.

Langkah 3: Menentukan unit analisis. Transkripsi dan analisis multimodal dilakukan dengan sangat intensif. Oleh karena itu diperlukan data sampel yang akan ditranskripsi dan dianalisis secara mendalam. Penentuan sampel data ini mengacu pada pertanyaan penelitian. Penelitian ini akan cenderung fokus pada unggahan Instagram Aku dan Polusi yang menggunakan foto/video anak dan perempuan disertai headline yang provokatif.

Langkah 4 : Transkripsi dan Analisis Data. Pada transkripsi multimodal, sebuah data akan diuraikan sesuai dengan mode yang dimilikinya. Dengan demikian transkripsi multimodal pada unggahan Instagram Aku dan Polusi yang berupa foto/video disertai tulisan akan berupa penguraian pilihan aktor, pose, gaze, komposisi, layout, pilihan leksikal dan sebagainya.

Unit analisis penelitian ini merupakan tangkapan layar 4 konten kampanye di bawah ini : 
Gambar 1. Foto seorang anak laki-laki disertai headline

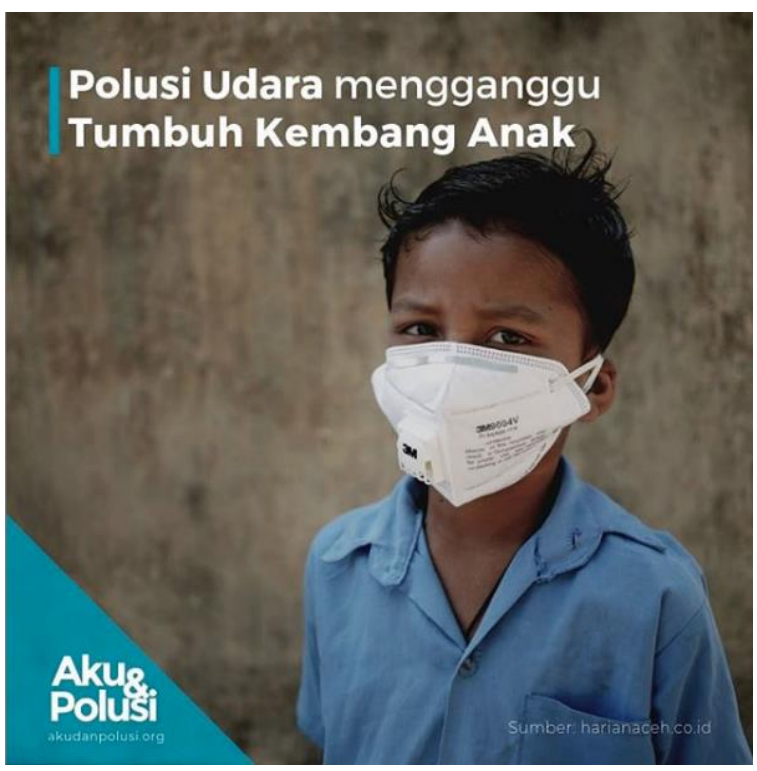

Sumber : Instagram @akudanpolusi unggahan 21 Maret 2019. Diakses pada 20 Desember 2019.

Gambar 2. Foto seorang ibu dengan anak disertai headline

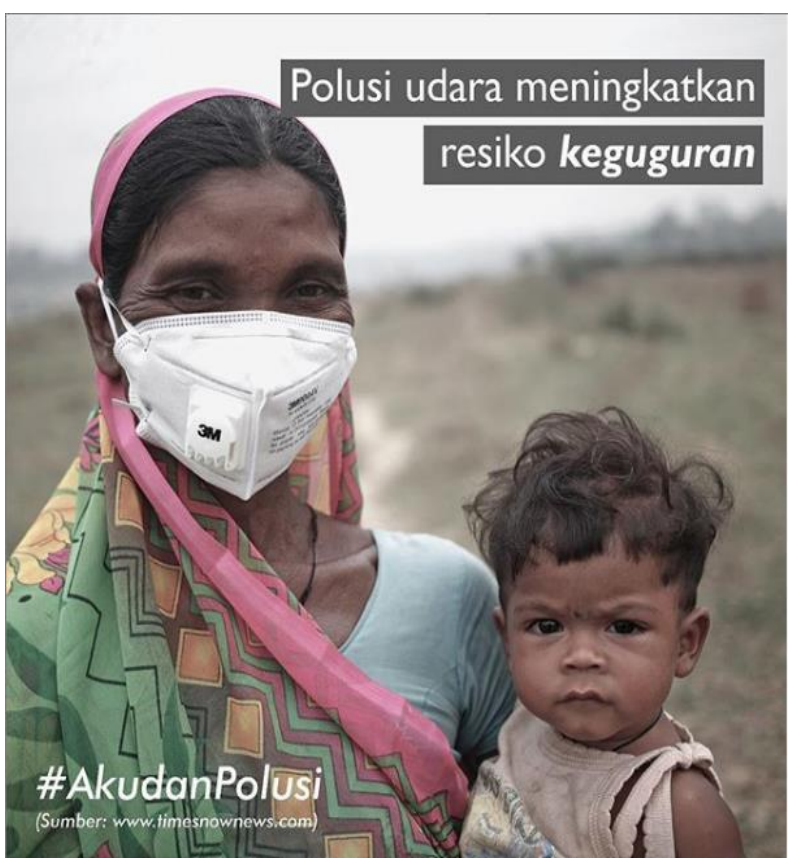

Sumber : Instagram @akudanpolusi unggahan 6 Desember 2018. Diakses pada 20 Desember 2019.
Gambar 3. Foto sekumpulan anak disertai headline

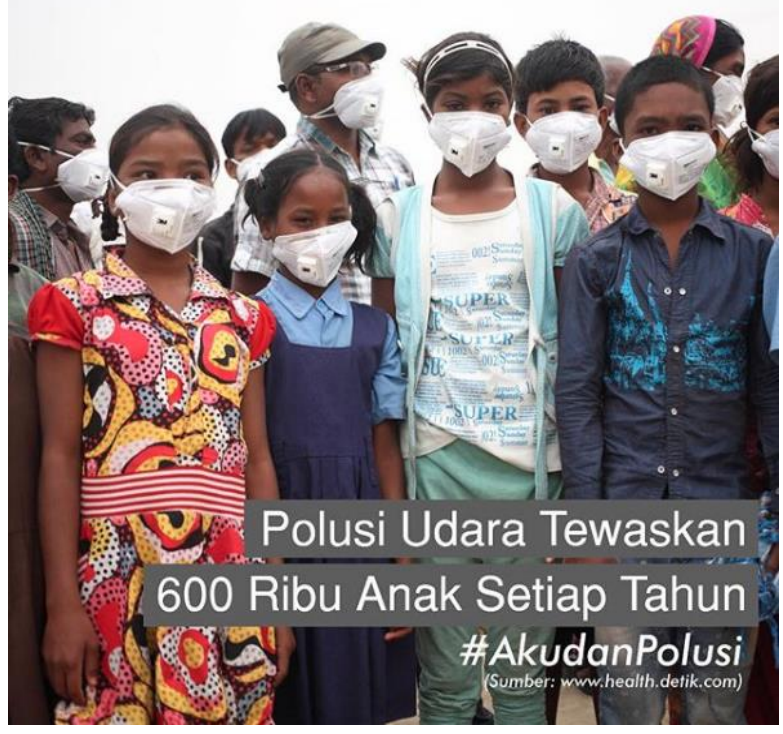

Sumber : Instagram @akudanpolusi unggahan 28 November 2018. Diakses pada 20 Desember 2019.

Gambar 4. Foto seorang anak perempuan disertai headline

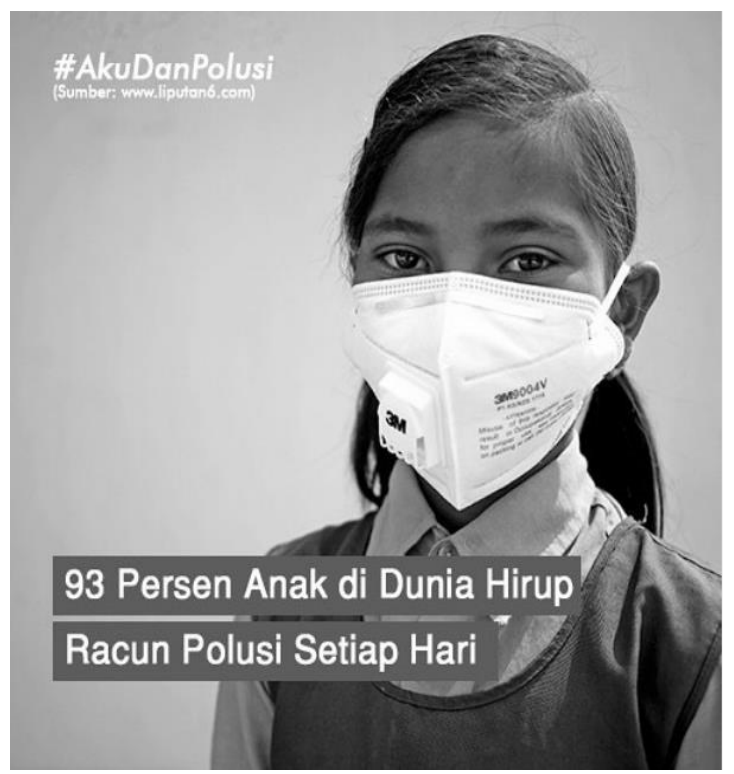

Sumber : Instagram @akudanpolusi unggahan 19 November 2018. Diakses pada 20 Desember 2019.

Pendekatan analisis yang digunakan penelitian ini bisa dibagi menjadi dua aspek besar yang saling melengkapi yaitu analisis 
pilihan visual dan analisis pilihan leksikal.

Pada analisis pilihan visual, fokus analisis tertuju pada pilihan fotografis, sinematik dan layout yang menyusun desain unggahan Instagram Aku dan Polusi. Analisis pilihan visual akan mengacu pada Visual Grammar menurut Kress dan van Leeuwen (2006) yakni sebuah kerangka untuk melakukan analisis terhadap visual images atau gambar visual.

Dengan mengacu pada pendekatan semiotika sosial pada analisis pilihan leksikal, penelitian ini memandang komponen leksikal terdiri dari berbagai opsi yang sedikit banyak akan menguntungkan pembuat wacana atau institusinya secara sosial dan ideologis (Blommaert \& Bulcaen, 2000). Analisis pilihan leksikal pada penelitian ini merujuk pada kerangka analisis wacana menurut Machin dan Mayr (2012).

\section{Hasil Penelitian}

Empat konten kampanye yang menjadi unit analisis penelitian ini bervariasi namun memiliki fitur umum yang sama yang sebagaimana yang dijabarkan pada tabel 1 dibawah ini.

Tabel 1. Elemen visual dan leksikal unit penelitian.

\begin{tabular}{clll}
\hline $\begin{array}{c}\text { Unit } \\
\text { analisis }\end{array}$ & \multicolumn{2}{c}{ Visual } & \multicolumn{1}{c}{ Leksikal } \\
\hline 1 & Foto anak laki- & "Polusi Udara \\
& laki & yang & Mengganggu \\
& mengenakan & Tumbuh \\
& masker khusus & Kembang \\
& anti polusi dan & Anak" \\
\hline
\end{tabular}

\begin{tabular}{|c|c|c|}
\hline & $\begin{array}{l}\text { mengenakan } \\
\text { seragam sekolah. }\end{array}$ & \\
\hline 2 & $\begin{array}{l}\text { Foto seorang ibu } \\
\text { yang mengenakan } \\
\text { masker khusus } \\
\text { anti polusi dan } \\
\text { pakaian harian } \\
\text { sedang } \\
\text { menggendong } \\
\text { balita yang tidak } \\
\text { mengenakan } \\
\text { masker. }\end{array}$ & $\begin{array}{l}\text { "Polusi Udara } \\
\text { Meningkatkan } \\
\text { Resiko } \\
\text { Keguguran" }\end{array}$ \\
\hline 3 & $\begin{array}{lr}\text { Foto } & \text { sekelompok } \\
\text { anak rang } & \text { yang } \\
\text { mengenakan } & \\
\text { masker } & \text { dan } \\
\text { pakaian } & \text { harian } \\
\text { serta } & \text { seragam } \\
\text { sekolah. } & \end{array}$ & $\begin{array}{l}\text { "Polusi udara } \\
\text { tewaskan } 600 \\
\text { ribu anak } \\
\text { setiap tahun" }\end{array}$ \\
\hline 4 & $\begin{array}{l}\text { Foto seorang anak } \\
\text { perempuan yang } \\
\text { mengenakan } \\
\text { masker dan } \\
\text { seragam sekolah. }\end{array}$ & $\begin{array}{l}\text { "93 Persen } \\
\text { Anak di Dunia } \\
\text { Hirup Racun } \\
\text { Polusi", }\end{array}$ \\
\hline
\end{tabular}

Keempat unit analisis merupakan foto sebagai elemen visual disertai headline dan caption sebagai elemen leksikal. Tidak dijelaskan secara mendetail mengenai jenis foto yang digunakan, namun dapat dilihat bahwa foto-foto tersebut merupakan staged photography atau documentary photography. Khalayak tidak diberikan keterangan apakah foto ini hasil rekaan atau merupakan foto dokumentasi yang menceritakan suatu peristiwa nyata. Fotografi mengingatkan khalayak tentang "bahasa dari suatu peristiwa", karena kamera mampu memperlihatkan suatu penampilan yang otentik, meskipun salah (Berger, 2001). Meskipun seorang fotografer tentu saja akan memberikan 
sejumlah arahan pada saat foto diambil ataupun pada saat proses editing, sebuah foto memiliki modalitas visual tingkat tinggi, dan karenanya disajikan sebagai representasi realitas yang nampak "naturalistik, tanpa perantara, dan tanpa kode" (Kress \& van Leeuwen, 2006).

Empat unit analisis dalam penelitian ini idealnya memiliki keterhubungan satu sama lain dikarenakan menggunakan gambar dengan aktor yang seragam, latar tempat dan waktu yang serupa, serta memiliki elemen penting yang menonjol yaitu adanya masker di dalam setiap gambarnya, namun caption yang menyertai masing-masing konten kampanye ini merupakan penjelasan singkat dari beberapa penelitian ilmiah mengenai dampak buruknya kualitas udara yang tidak saling terhubung satu sama lain. Sehingga masing - masing konten kampanye berfungsi sebagai teks yang otonom, yang didesain untuk secara persuasif mengkomunikasikan bahaya yang muncul karena dampak buruknya kualitas udara dan mendukung kampanye advokasi Aku dan Polusi. Analisis pilihan visual dan leksikal menunjukkan dua strategi wacana yang yang digunakan, dijabarkan dibawah ini.

Fear Appeals pada Visualisasi Dampak Polusi Udara

Represented participant adalah istilah dalam MDA untuk aktor yang ditampilkan di dalam teks, yang pada unit analisis ini merupakan anak dan perempuan. Struktur relasi antara represented participants pada unit analisis penelitian ini sangat analitik sekaligus sangat simbolik. Foto yang menyertai konten kampanye yang dijadikan unit analisis tidak menunjukan adanya partisipan yang sedang melakukan sesuatu untuk partisipan lain, melainkan tentang cara partisipan ditempatkan bersama - sama untuk membentuk makna keseluruhan yang lebih besar. Kress dan van Leeuwen (2006) menyebut partisipan dengan relasi seperti ini sebagai "Carrier" dan "Possesive Attribute".

Pada unit analisis penelitian ini, possesive attribute yang paling menonjol adalah masker anti polusi yang dikenakan represented participant di setiap foto yang ada. Secara komposisi visual, masker anti polusi ditempatkan sebagai point of interest dari setiap foto. Hal ini ditandai dengan beberapa ciri seperti masker diposisikan pada bagian terdepan dengan fokus yang tajam, dan dalam sudut pandang tertentu, terlihat tidak pada tempatnya. Secara mendetail, unit analisis ini menunjukkan bahwa masker yang digunakan terlihat terlepas dari konteks karena dikenakan oleh aktor yang mengenakan baju sehari - hari, atau bahkan beberapa mengenakan seragam sekolah. Hal ini tampak tidak wajar karena di kondisi normal, khalayak tidak 
mengenakan masker dalam kehidupan sehari - hari. Masker pada unit analisis ini berfungsi untuk menyampaikan potensi bahaya di masa depan apabila permasalahan polusi udara tidak diselesaikan hingga membuat masyarakat sampai perlu menggunakan masker khusus untuk aktivitas sehari-hari. Hal ini juga memunculkan impresi yang menakutkan bahwa tindakan penanggulangan seperti penggunaan masker biasa tidak lagi memadai karena tingkat polusi udara yang dihadapi cenderung semakin parah.

Pada unit analisis di dalam headline poster, "Polusi Udara" ditampilkan sebagai agen atau pihak yang melakukan sesuatu. Kata kerja yang dipilih menunjukkan terjadinya material process atau proses melakukan sesuatu. Kata kerja dalam material process menunjukkan adanya aksi nyata yang biasanya menghasilkan sesuatu.

\section{"Polusi Udara mengganggu Tumbuh Kembang Anak" (Aku dan Polusi, 2018) \\ "Polusi Udara meningkatkan resiko keguguran" (Aku dan Polusi, 2018) \\ "Polusi Udara Tewaskan 600 Ribu Anak Setiap Tahun" (Aku dan Polusi, 2018)}

Kata kerja yang digunakan merupakan bentuk aktif dari sebuah kata kerja pasif. Polusi udara ditampilkan secara aktif, dengan menempatkan kata kerja aktif dan membuat polusi udara menjadi agen yang "melakukan suatu hal" meskipun faktanya polusi udara muncul karena kegiatan aktif lain, seperti penggunaan kendaraan tidak ramah lingkungan atau pembangunan pembangkit listrik berbahan bakar batu bara.

Headline pada gambar 1, 2 dan 3 menunjukkan upaya yang jelas untuk menampilkan adanya dramatisasi dari klausa berikutnya. Hal ini menunjukan adanya suppression atau penghilangan suatu konsep dari klausa ini, yaitu penyebab aktif polusi udara.

Suppression yang dilakukan pada headline "Polusi Udara mengganggu Tumbuh Kembang Anak", "Polusi Udara meningkatkan resiko keguguran", dan "Polusi Udara Tewaskan 600 Ribu Anak Setiap Tahun" memiliki beberapa pengaruh seperti yang dijelaskan oleh Machin dan Mayr (2012). Pertama, pelaku aksi dan tanggung jawab atas aksi tersebut dihilangkan. Dalam hal ini penyebab polusi dan pihak yang bertanggung jawab tidak dibicarakan. Kedua, konsep ini menjadi suatu entitas baru dan digunakan secara umum oleh awam. Polusi udara menjadi suatu konsep baru yang menyebabkan resiko kesehatan untuk anak yang membuat pemirsa justru lupa akan tindakan yang memunculkan polusi udara dan membahayakan kesehatan anak.

Penekanan kepada aksi seperti, “mengganggu”, “meningkatkan", "tewaskan", yang muncul karena penghilangan penyebab polusi, membuat 
khalayak terhindar dari pembicaraan mengenai agen, waktu kejadian, dan detail kejadian karena adanya proses simplifikasi yang menjadi dampak ketiga. Keempat, proses suppression membuat teks yang disampaikan menjadi sangat padat sehingga detail peristiwa menjadi dikurangi. Pada unit analisis ini detail peristiwa bahkan tidak tersampaikan melalui caption yang menyertai foto dan headline terkait.

Selain suppression, terdapat pula proses aggregation dalam headline yang melakukan kuantifikasi dan memperlakukan partisipan sebagai bagian dari data "statistik". Hal ini tampak pada gambar 4 dengan headline, "93\% Anak di Dunia Hirup Racun Polusi Setiap Hari”. Proses aggregation digunakan untuk memberikan impresi sebuah riset yang objektif dan secara saintifik kredibel namun sebenarnya tidak memberikan angka yang spesifik (Machin \& Mayr, 2012). Headline ini sebenarnya merujuk pada penelitian ilmiah oleh WHO yang menunjukkan bahwa 93\% anak hidup di wilayah yang kualitas udaranya lebih buruk dari index yang diterapkan oleh WHO (WHO, 2018).

Strategi wacana yang digunakan melalui pilihan visual dan leksikal pada unit analisis penelitian ini menunjukkan adanya penekanan dalam representasi dampak polusi udara. Penekanan ini menggunakan pendekatan fear appeals dengan ciri penyampaian persuasif yang menunjukkan ancaman-ancaman polusi udara terhadap anak apabila permasalahan polusi udara ini tidak segera diatasi.

\section{Penggambaran Anak sebagai Pemicu Reaksi Emosional Ibu}

Pandangan mata partisipan yang ditampilkan kepada khalayak membentuk suatu vektor yang dibangun oleh garis pandangan mata partisipan, yang kemudian menghubungkan partisipan dengan khalayak. Melalui pandangan mata ini, terbangun suatu kontak meskipun hanya dalam tataran imajiner. Semua unit analisis pada penelitian ini memiliki fitur dan vektor yang sama dimana represented participants memandang ke arah khalayak secara langsung yang disebut demand images (Kress \& van Leeuwen, 2006).

Demand images pada unit penelitian ini merujuk pada “the participant's gaze (and the gesture, if present) demands something from the viewer, demands that the viewer enter into some kind of imaginary relation with him or her" (Halliday, 2004). Demand images digunakan untuk menuntut khalayak lebih terlibat, dalam hal ini memahami dampak kualitas udara yang memburuk. Pandangan mata represented participants menarik penonton lebih terhubung dengan kondisi yang mereka alami melalui cerita dengan masker yang digunakan. Penggunaan demand images ini juga memaparkan 
tanggung jawab yang ditanggung khalayak atas kondisi yang dialami represented participants. Konten kampanye ini meletakkan tanggung jawab atas kualitas udara pada khalayak.

Penggunaan close up shot pada setiap unit analisis ini menempatkan khalayak pada close personal distance dari represented participants. Bagi anak, jarak sosial terdekatnya dimulai dari keluarga, sehingga jelas konten kampanye ini ditujukan bagi orang tua, terutama ibu karena anak tidak memiliki kemampuan untuk melakukan apa yang direkomendasikan oleh kampanye. Anak bergantung kepada orang tua dan pengasuh utama, terutama ibu, di dalam maupun di luar rumah, untuk bertindak atas nama mereka terutama berkaitan dengan keselamatan dan kesehatan anak (Institute of Medicine And National Research Council, 2015).

\section{Penempatan}

represented participants pada suatu latar tempat yang tidak ditampilkan dengan jelas, tidak fokus dan dapat digantikan, membuat khalayak ditempatkan pada posisi yang terhubung dengan represented participants. Impresi yang muncul adalah bahwa ini bisa menimpa siapa saja, terjadi di mana saja dan dalam waktu dekat semakin kuat. Pemberian tone warna dengan saturasi yang rendah digunakan untuk menyampaikan sesuatu yang kontemplatif (Kress \& van
Leeuwen, 2006). Sehingga sasaran pesan kampanye ini, yakni ibu, diajak untuk berpikir bahwa bisa saja buruknya kualitas udara ini berpengaruh pada kesehatan anaknya yang membuat kampanye ini semakin jelas memancing kegelisahan.

\section{Pembahasan}

Dalam menggambarkan ancaman dampak polusi udara, unit analisis ini menekankan pada bahaya serta konsekuensi yang fatal untuk anak. Sasarannya adalah orang tua, terutama ibu yang tidak melakukan tindakan untuk mengurangi polusi udara, meskipun orang tua terutama ibu juga memiliki resiko terpapar polusi udara. Penggunaan taktik menakut-nakuti seperti ini bermata dua karena memunculkan problematika etis dan pertanyaan tentang efektivitas penggunaan pendekatan fear appeals. Rasa takut bisa memunculkan dampak kontra produktif karena cenderung tidak secara akurat dan tidak jujur mengungkapkan fakta, serta memiliki potensi melebih-lebihkan resiko ancaman yang ada hingga membuat khalayak ketakutan atau bahkan memicu misleading (Guttman \& Salmon, 2004).

Penggambaran yang parsial akan sebab utama polusi udara dan siapa saja yang memiliki resiko terpapar juga mengaburkan realitas bahwa polusi udara terbesar berasal dari asap kendaran dan pembangkit listrik batu bara yang ada di sekitar Jakarta. Lebih lanjut, realitas bahwa 
belum ada kebijakan terkait yang mengupayakan pengurangan polusi udara juga turut hilang. Hal ini menyebabkan munculnya realitas baru yang ditawarkan bahwa polusi udara harus ditangani dengan mengatasi dampak yang ditimbulkan seperti mengenakan masker anti polusi bagi anak karena anak digambarkan sebagai kelompok yang paling rentan.

Menempatkan anak pada suatu iklan atau penawaran merupakan strategi yang digunakan untuk menyasar orang tua. Dengan mengusik kegelisahan dan perasaan ketidakcakapan, pemasar bisa dengan mudah menyampaikan penawaran dengan janji membawa kebahagiaan bagi anak. Sehingga jelas visualisasi ini menyasar orang tua sebagai pihak yang bertanggung jawab atas solusi dampak polusi udara bagi anaknya atau anak secara umum.

Secara natural, permasalahan lingkungan memengaruhi semua pihak, termasuk orang tua, baik ibu maupun ayah, perempuan ataupun laki-laki. Namun, gender memiliki peran yang signifikan sehubungan dengan perbedaan dampak suatu isu lingkungan yang dirasakan. Gender tidak hanya menentukan kemampuan laki-laki dan perempuan untuk mengatasi permasalahan lingkungan, namun juga adanya ketidaksetaraan struktural yang tidak terlihat yang membuat perempuan menerima dampak secara tidak proporsional dari suatu isu lingkungan. Meskipun cenderung menerima dampak yang lebih, penelitian menunjukkan bahwa ibu dan perempuan memiliki tingkat kepedulian terhadap suatu isu lingkungan lebih dari pada laki-laki yang membuat ibu dan perempuan terus menerus menjadi target pesan terkait permasalahan lingkungan (Brough, Wilkie, Ma, Isaac, \& Gal, 2016).

Penelitian menunjukkan bahwa pesan dengan pendekatan fear appeals efektif hanya jika penerima pesan memiliki self efficacy, yakni kemampuan untuk mengatasi permasalahan yang tinggi (O’Neill \& Nicholson-Cole, 2009). Individu dengan posisi sosial dan psikologis yang lebih baik akan merespons pesan yang menakutkan dengan lebih baik (Hastings, Stead, \& Webb, 2004). Bagi individu dengan kedudukan sosial dan psikologis yang kurang, pesan yang menakutkan akan membuat mereka merasa lebih buruk, cemas, atau bahkan marah dan defensif.

Terkait dengan penggunaan fear appeals berdasarkan gender, penggunaan pendekatan sangat efektif memengaruhi sikap dan perilaku, terutama apabila ditujukan bagi perempuan (Tannenbaum et al., 2015). Perempuan, khususnya ibu, menurut Nicholson-Cole (2005), memiliki orientasi yang sangat khusus terhadap masa depan anaknya. Berkaitan dengan isu lingkungan, bagi ibu, gambaran masa depan 
terkait lingkungan akan dikaitkan dengan masa depan anaknya.

Meski begitu, walaupun ibu memiliki keinginan kuat untuk memberikan perubahan, termasuk apabila perubahan itu bisa mereka lakukan atau mampu mereka beli, namun pada saat yang bersamaan kelompok ini juga merasa tidak mampu melakukan apapun (Nicholson-Cole, 2005). Hal ini membuat penempatan kelompok rentan sebagai sasaran pesan dengan cara menakut - nakuti menjadi problematis tidak tepat secara etis karena bisa memunculkan konflik internal seperti sikap menyalahkan diri sendiri atau penurunan kepercayaan diri apabila tidak berhasil melakukan rekomendasi tindakan yang disampaikan.

\section{Penutup}

Peneliti berpendapat visualisasi dampak polusi udara yang diteliti dalam penelitian ini problematik secara etis karena secara visual dan linguistik menggunakan taktik menakut-nakuti, terutama ketika taktik ini menggunakan anak sebagai kelompok rentan untuk menyasar ibu yang juga merupakan kelompok rentan. Strategi wacana yang digunakan, penggunaan pendekatan fear appeals dan penggambaran anak sebagai pemicu reaksi emosional, bekerja dengan disadari atau tidak menghilangkan sebab utama polusi udara dan aktor sosial yang melatarbelakanginya yaitu pembuat kebijakan. Ketika hal ini disampaikan oleh kampanye advokasi yang tujuan besarnya mengubah kebijakan terkait standar kualitas udara, maka efektivitasnya perlu dipertanyakan. Dengan membangun pesan yang menakutkan tentang dampak polusi udara, menggunakan anak sebagai represented participants, serta menyampaikan kepada ibu sebagai target pesan, maka tanggung jawab tersedianya udara yang baik menjadi beban yang diletakkan di pundak ibu. Hal ini mengonfirmasi adanya gender gap dalam komunikasi lingkungan, di mana perempuan selalu dijadikan target pesan, produk atau gerakan karena perempuan cenderung lebih mau terlibat dan peduli terhadap suatu isu lingkungan meskipun perempuan sendiri merupakan kelompok rentan yang suara dan keterlibatannya secara sistematis diabaikan dalam pembuatan kebijakan terkait lingkungan.

Komunikasi lingkungan adalah sebuah komunikasi yang secara esensial selalu bersifat multimodal karena dirancang untuk menggunakan tidak hanya bahasa namun juga elemen visual untuk membuat makna. Multimodal discourse analysis yang digunakan pada penelitian ini sangat tepat karena memberikan kesempatan untuk menginterpretasikan pilihan elemen visual dan leksikal yang sepertinya banal dan umum digunakan namun memiliki makna yang lebih dalam atau bahkan tersembunyi. Penelitian ini diharapkan dapat 
menunjukkan pendekatan multimodal dan bisa memberikan gambaran wacana, penekanan, ambiguitas yang ada pada suatu komunikasi lingkungan. Namun selayaknya riset semiotika sosial, interpretasi dari visualisasi yang dipaparkan tidak bisa digeneralisasikan sebagai gambaran bagaimana khalayak menanggapi dan memahaminya. Interpretasi khalayak merupakan hal yang sangat subjektif dan kontekstual.

\section{Daftar Pustaka}

Berger, J. (2001). Selected Essays of John Berger (G. Dyer, Ed.). New York: Vintage International.

Blommaert, J., \& Bulcaen, C. (2000). Critical Discourse Analysis. Аnnu. Rev. Anthropol, 29, 447-466.

Brough, A. R., Wilkie, J. E. B., Ma, J., Isaac, M. S., \& Gal, D. (2016). Is EcoFriendly Unmanly? The GreenFeminine Stereotype and Its Effect on Sustainable Consumption. Journal of Consumer Research, 43, 567-582. https://doi.org/10.1093/jcr/ucw044

Guttman, N., \& Salmon, C. T. (2004). Guilt, fear, stigma and knowledge gaps: Ethical issues in public health communication interventions. Bioethics, Vol. 18, pp. 531-552. https://doi.org/10.1111/j.14678519.2004.00415.x

Halliday, M. A. . (2004). An Introduction to Functional Grammar (3rd Ed). London: Hodder Arnold.

Hastings, G., Stead, M., \& Webb, J. (2004).
Fear appeals in social marketing: Strategic and ethical reasons for concern. Psychology and Marketing, 21(11), 961-986. https://doi.org/10.1002/mar.20043

Indonesian Center For Environmental Law. (2019). [Siaran Pers Bersama] Sidang Perdana, Koalisi Ibukota Tuntut Udara Bersih - ICEL. Retrieved from https://icel.or.id/berita/siaranpers/siaran-pers-bersama-sidangperdana-koalisi-ibukota-tuntut-udarabersih/

Institute of Medicine And National Research Council. (2015). THE NATIONAL ACADEMIES PRESS (L. Allen \& B. B. Kelly, Eds.). https://doi.org/10.17226/19401

Kress, G., \& van Leeuwen, T. (2006). Reading Image (2nd Ed). London and New York: Routledge.

Machin, D., \& Mayr, A. (2012). How to Do Critical Discourse Analysis_ A Multimodal Introduction. Sage.

Mongabay. (2019). Kala Kualitas Udara Jakarta Buruk, Warga Gugat Pemerintah ke Pengadilan: Mongabay.co.id. Retrieved from https://www.mongabay.co.id/2019/07 /07/kala-kualitas-udara-jakarta-burukwarga-gugat-pemerintah-kepengadilan/

Moser, S. C., \& Dilling, L. (2004). Making Climate Hot. Environment: Science and Policy for Sustainable Developmentt, 46(10), 32-46. https://doi.org/10.1080/00139150409 605820

Nathania, B., \& Fadhillah, F. (2020). RANGKUMAN PERJALANAN GUGATAN WARGA NEGARA 
TENTANG POLUSI UDARA JAKARTA PADA TAHUN 2019. Jakarta.

Nicholson-Cole, S. A. (2005). Representing climate change futures: A critique on the use of images for visual communication. Computers, Environment and Urban Systems, $29(3$ SPEC. ISS.), 255-273. https://doi.org/10.1016/j.compenvurbs ys.2004.05.002

O’Neill, S., \& Nicholson-Cole, S. (2009). "Fear won't do it" Visual and iconic representations.

Science Communication, 30(3), 355-379. https://doi.org/10.1177/10755470083 29201

Reser, J. P., \& Bradley, G. L. (2017). Fear Appeals in Climate Change Communication. Oxford Research Encyclopedia of Climate Science, (June), 1-66. https://doi.org/10.1093/acrefore/9780 190228620.013.386

Ruiter, R., \& Kok, G. (2012). Planning to
Frighten People? Think Again! In M. Kools \& C. Abraham (Eds.), Writing Health Communication : An EvidenceBased Guide (pp. 117-133). https://doi.org/http://dx.doi.org/10.41 35/9781446288054.n8 Print

Seo, K., Dillard, J. P., \& Shen, F. (2013). The Effects of Message Framing and Visual Image on Persuasion. Communication Quarterly, 61(5), 564-583.

https://doi.org/10.1080/01463373.201 3.822403

Tannenbaum, M. B., Hepler, J., Zimmerman, R. S., Saul, L., Jacobs, S., Wilson, K., \& Albarracín, D. (2015). Supplemental Material for Appealing to Fear: A Meta-Analysis of Fear Appeal Effectiveness and Theories. Psychological Bulletin, 141(6), 1178-1204. https://doi.org/10.1037/a0039729.sup $\mathrm{p}$

WHO. (2018). Air Pollution and Child Health: Prescribing Clean Air. Geneva. 